\title{
АКТУАЛЬНІ ПИТАННЯ ЗАСТОСУВАННЯ МІЖНАРОДНИХ ПРАВОВИХ СТАНДАРТІВ ПІД ЧАС ДОСУДОВОГО РОЗСЛІДУВАННЯ
}

\begin{abstract}
ЦИЛЮРИК Інна - кандидат юридичних наук, доцент кафедри кримінального права і процесу Інституту права, психології та інноваційної освіти Національного університету «Львівська політехніка»
\end{abstract}

ORCID ID: https://orcid.org/0000-0002-4776-2278

DOI 10.32782/NP.2021.4.14

Статтю присвячено дослідженню питання застосування міжнародних правових стандартів під час досудового розслідування. Під час написання статті авторка з’ясувала, шзо реалії, у яких знаходиться Украӥна у зв'язку з європейською інтеграиією та приведенням кримінального процесуального законодавства до норм і приниипів міжнародно-правових актів, викликають необхідність переосмислення багатьох положень кримінального прочесу. Адже захист прав, свобод та законних інтересів особи, а також суспільства та держави від кримінальних правопорушень у сучасних умовах неможливо забезпечити без еббективного дотримання європейсъких та міжнародних стандартів кримінального судочинства, а їх імплементація у вітчизняне законодавство є особливо необхідною. Відтак посилення процесуальних гарантій реалізачій прав, свобод $i$ законних інтересів особи в кримінальному провадженні, а також удосконалення регулювання кримінальноӥ процесуальної діяльності не може здійснюватися у відриві від загальновизнаних міжнародних правових стандартів $i$ практики ЕСПЛ як регулятора правових елементів підтримання правопорядку, охорони миру та безпеки людства. У прочесі дослідження автор сбормулювала власні висновки.

Ключові слова: права, свободи, законні інтереси, кримінально-процесуальна діяльність, міжнародно-правові стандарти.

\section{Постановка проблеми}

3 часу здобуття Україною незалежності пріоритетною проблемою правової думки є захист прав, свобод та законних інтересів людини. Особливого специфічного змісту і значення це питання набуває у сфері кримінального судочинства. Очевидним $є$ також те, що в умовах євроінтеграції України цей аспект користується підвищеною увагою 3 боку міжнародних інституцій, оскільки сьогодні урядом нашої країни ратифіковано значний масив міжнародно-правових актів у сфері захисту прав і свобод людини.

Аналіз останніх досліджень і публікацій

На різних етапах розвитку кримінального процесу питанням запровадження міжнародних правових стандартів у вітчизняне кримінальне процесуальне законодавство присвятили свої праці С. Є. Абламський, Ю. М. Грошевий, О. В. Капліна, В. Т. Маляренко, М. М. Михеєнко, В. Т. Нор, М. А. Погорецький, Д. В. Сімонович, В. Г. Уваров, А. Д. Удалова, Т. Г. Фоміна, О. О. Юхно та багато інших провідних учених. Проте після набрання чинності КПК України 2012 року це питання дістало новий вектор свого розвитку й дослідження, адже на законодавчому рівні визначено, що кримінальне процесуальне законодавство України застосовується з урахуванням практики Свропейського суду з прав людини. Зважаючи на це, у наш час усе частіше національні суди під час постановлення ухвал і винесення ви- 


\section{Кримінальне право, кримінальний процес та криміналістика}

років спираються на практику цього міжнародного судового органу, юрисдикція якого поширюється на всі держави-члени Ради Европи, що ратифікували Конвенцію про захист прав людини і основоположних свобод. Не є винятком також Україна.

\section{Виклад основних положень}

У контексті дослідженого питання О. В. Капліна цілком доречно зазначила, що реформування національного законодавства неможливе без урахування відповідного досвіду міжнародної спільноти. Ставши на демократичний шлях розвитку і визначивши як завдання побудову правової держави, Україна повинна сприйняти глибоко гуманістичні цінності, що набули статусу загальновизнаних норм і стандартів, та імплементувати найпрогресивніші з них у свою правову систему [1].

Отже, нові реалії, у яких знаходиться Україна у зв'язку з європейською інтеграцією та приведенням кримінального процесуального законодавства до норм і принципів міжнародно-правових актів, викликають необхідність переосмислення багатьох положень кримінального процесу. Адже захист прав, свобод та законних інтересів особи, а також суспільства та держави від кримінальних правопорушень у сучасних умовах неможливо забезпечити без ефективного дотримання європейських та міжнародних стандартів кримінального судочинства, a їх імплементація у вітчизняне законодавство є особливо необхідною. Відтак посилення процесуальних гарантій реалізації прав, свобод і законних інтересів особи у кримінальному провадженні, а також удосконалення регулювання кримінальної процесуальної діяльності не може здійснюватися у відриві від загальновизнаних міжнародних правових стандартів і практики ЕСПЛ як регулятора правових елементів підтримання правопорядку, охорони миру та безпеки людства [2, с. 48].

Сьогоденні проблеми і вимоги, які стоять перед Україною у зв’язку з інтеграційними процесами, свідчать про те, що захист прав, свобод і законних інтересів особи набуває все більшого значення. За таких умов розроблення і практичне втілення дієвих правових механізмів захисту прав, свобод та законних інтересів особи неможливе без урахування загальновизнаних міжнародноправових стандартів і принципів у цій сфері. Саме тому, на наше переконання, подальше вдосконалення кримінального процесуального законодавства України, впровадження нових інститутів має відбуватися не інакше як 3 урахуванням загальновизнаних європейських стандартів і принципів здійснення кримінального судочинства. Тож, безумовно, на цьому історичному етапі розвитку нашої держави порушене питання вимагає осмислення сутності та правової природи міжнародно-правових стандартів захисту особи в кримінальному процесі.

3 огляду на пріоритетність окресленого напряму, наразі Україна активно підтримує міжнародне співробітництво з членами європейської спільноти у різних сферах діяльності, що вимагає постійного приєднання до чинних багатосторонніх міжнародних договорів. На цій основі здійснюється приведення національного законодавства у відповідність до загальновизнаних норм і стандартів. Зокрема, це стосується кримінального процесу України, що є специфічним видом діяльності уповноважених службових осіб, які в межах і порядку, передбачених законом, можуть застосовувати правообмежувальні заходи (затримання, привід, тимчасове вилучення, арешт майна, обрання запобіжних заходів тощо).

Більше того, в умовах концептуального реформування національного законодавства потреба зосередження уваги на обов'язковості впровадження міжнародноправових стандартів захисту прав і свобод особи в кримінальному процесі, як ніколи раніше, стає актуальною для нашої держави. Відтак існує потреба привернути увагу практиків і законотворців до цієї проблеми 3 метою спонукання їх до формування відповідної концепції вдосконалення законодавства. Отже, позитивний досвід міжнародного співробітництва свідчить про те, що побудова нормальних відносин 3 іншими державами базується на теорії і практиці міжнародного права та обумовлює необхідність створення добре налагодженого державного механізму правового регулювання. 
Від цього напряму державного управління залежить ефективність імплементації норм міжнародного права як у сфері взаємовідносин між державами, так і при їх реалізації відповідно до норм національного законодавства [3]. Вказане також обумовлено взятими Україною зобов'язаннями щодо забезпечення захисту прав і свобод людини в повному обсязі, а у разі їх порушення створення всіх умов для поновлення. I, як слушно зауважив М. Орзіх, конституційні права і свободи людини не можуть бути вужчими за змістом від міжнародно-правових стандартів, і до цього повинні прагнути всі народи [4, с. 8]. У цьому відношенні слід відзначити вимоги ст. 22 Конституції України, згідно з якими при прийнятті нових законів або внесенні змін до чинних не допускається звуження змісту та обсягу чинних прав i свобод.

Таким чином, реформування правової системи України пов'язано з утвердженням ефективних правових інститутів, які 6 гарантували розвиток нашої держави як соціальної, демократичної та правової.

Слiд взяти до уваги те, що міжнародноправові стандарти кримінального судочинства мають важливе значення не лише для теорії права, а й для правозастосовної діяльності. По-перше, аргументуючи та приймаючи свої рішення на підставі таких стандартів, державні органи та посадові особи реалізують конституційні положення 3 питань застосування міжнародних договорів, які є частиною національного законодавства. Подруге, застосування загальновизнаних міжнародних стандартів захисту прав і свобод людини є свідченням формування нової правової системи, у якій, дійсно, права і свободи кожної людини та їх гарантії визначають зміст і спрямованість діяльності держави. По-третє, формування суддівської позиції на основі міжнародно-правових стандартів захисту прав і свобод людини сприяе довірі з боку громадян, які очікують на радикальні зміни у цій сфері.

Аналізуючи систему універсальних міжнародних правових актів щодо протидії катуванням та іншим формам негуманного поводження 3 людиною, Е. Б. Тітов зазначив, що із середини XX-го століття чимало зусиль було витрачено державами на розроблення та реалізацію міжнародних стандартів захисту прав людини. Ці зусилля знайшли свій прояв у формуванні масштабної системи таких стандартів. Учений відзначив, що така система включає норми універсального, регіонального, субрегіонального та локального характеру, які органічно доповнюють, підсилюють, а іноді й дублюють одна одну, формуючи тим самим ефективний міжнародно-правовий механізм забезпечення, захисту і відновлення основоположних прав і свобод людини [5, с. 387].

Як свідчить досвід провідних країн (США, Німеччина, Франція, Великобританія тощо), процес імплементації міжнародно-правових стандартів захисту прав і свобод людини у національне законодавство не відбувається відразу, адже це явище не миттєвого характеру. Для цього процесу потрібен тривалий час.

У цілому видається можливим стверджувати, що 3 прийняттям КПК України доктрина кримінального процесу та правозастосовна практика отримали низку новел, однією 3 яких стало запровадження положення щодо застосування в кримінальному провадженні практики Европейського суду з прав людини.

Аналізуючи діяльність Европейського суду з прав людини, А. Столітній вказує, що у своїх рішеннях ЄСП $А$ конкретизує і деталізує норми Конвенції і протоколів до неї, розкриває зміст правових оціночних понять і формулює правові позиції, при цьому застосування юридичних норм охоплюе три питання: юридичний аналіз конкретних випадків, які підлягають вирішенню, тлумачення Конвенції і протоколів, їх послідовний логічний розвиток. Автор звертає увагу на останній елемент процедури правозастосування, який свідчить про те, що Европейський суд виходить за межі конкретної справи, яка ним розглядається по суті, розробляючи в таких процедурах висновки, котрі є зразками для інших аналогічних випадків та отримують визнання як належне регулювання спірних кримінальних процесуальних правовідносин [6, с. 27]. 3 приводу вказаного зауважимо, що яскравим прикладом є позиція ЄСП 


\section{Кримінальне право, кримінальний процес та криміналістика}

«Бендерський проти України», де Суд підкреслює, що право на захист випливає 3 права на справедливий судовий розгляд. Цей висновок Суд робить, враховуючи ті обставини, що національні судові органи не надали особливої та чіткої реакції щодо обгрунтованих доводів особи, що зумовило незабезпечення права на справедливий судовий розгляд $[7$, с. 310]. I, як цілком слушно 3 цього питання зауважив С. Д. Шаталюк, норма ч. 3 ст. 6 Конвенції оперує саме терміном «право на захист», а не «право на юридичну допомогу» [1].

Ми цілком підтримуємо таку позицію, оскільки в правовій європейській країні, якою прагне стати України, кожний суддя має бути професіоналом своєї справи, а при постановленні ухвали чи винесенні вироку за можливості посилатися на відповідну практику ЕСП $\curlywedge$. Така власна обізнаність додатково буде свідчити про справедливість, обгрунтованість та вмотивованість як власної позиції судді, так і прийнятого ним рішення, що, у свою чергу, мінімізує сумніви в його об’єктивності, а отже, підвищить авторитет судової гілки влади загалом.

Водночас, як констатував О. О. Юхно, законодавцем так і не було ліквідовано низку інститутів (наприклад, депутатської недоторканності), що не може не вплинути на ефективність роботи правоохоронних органів, а також своєчасну протидію корупції в державі. Сучасні умови протидії та запобігання злочинності вимагають від слідчого дедалі більшої професійної майстерності. Незважаючи на прийняття КПК України, питання подальшого удосконалення і демократизації досудового розслідування вирішуються дуже повільно. Це, передусім, пояснюється відсутністю єдиної концепції щодо його реформування, яка має будуватися на професійно напрацьованих науковцями і практиками обгрунтованих засадах, що випливають 3 пізнаної реальної дійсності суспільних відносин, а також із позитивних факторів у практиці функціонування вітчизняних і зарубіжних процесуальних інститутів [8, с. 164].

На нашу думку, новелізація щодо застосування практики ЕСП $\Lambda$ призвела до того, що сучасна парадигма захисту прав, свобод і законних інтересів особи в міжнародному вимірі значно зросла. Так, ч. 2 ст. 8 КПК України передбачено, що принцип верховенства права у кримінальному провадженні застосовується з урахуванням практики Европейського суду з прав людини. У свою чергу, у ч. 5 ст. 9 КПК України закріплено, що кримінальне процесуальне законодавство України застосовується 3 урахуванням практики Европейського суду 3 прав людини. Отже, буквальне тлумачення змісту наведених положень дає змогу зазначити, що застосування практики ЕСП А стосується лише засади верховенства права та законності, адже в інших двадцяти засадах (глава 2 КПК України) іншого не передбачено. Проте зрозуміло, що законодавець не обмежився застосуванням практики ЕСП лише стосовно вказаних двох засад. Тому, усвідомлюючи той факт, що захист особи, охорона прав, свобод та законних інтересів особи у кримінальному провадженні є першочерговим завданням, законодавцю слід було закріпити окрему засаду стосовно застосування практики $\mathrm{ECП} \lambda$ у кримінальному провадженні.

Водночас, згідно 3 ч. 2 ст. 1 КПК України, міжнародні договори, згода на обов'язковість яких надана Верховною Радою України, є однією зі складових частин кримінального процесуального законодавства України. Разом із тим, відповідно до ст. 9 Конституції України, чинні міжнародні договори, згода на обов'язковість яких надана Верховною Радою України, є частиною національного законодавства України.

У контексті розгляду питань реалізації рішень Европейського суду з прав людини та норм міжнародно-правових актів у кримінальному процесі України В. Г. Уваров зазначає, що під правовою дефініцією «загальновизнаний міжнародно-правовий стандарт» слід розуміти норми та принципи, закріплені в міжнародно-правових актах, що мають обов'язковий або рекомендаційний характер для держав-членів, що ратифікували міжнародний договір, а також містять відповідні критерії, якими вони зобов'язані керуватися під час законотворчої діяльності при удосконаленні національного законодавства [9]. 
Дещо схожу наукову позицію висловила і М. Г. Моторигіна, зокрема, про те, що загальновизнані принципи міжнародного права у сфері кримінального судочинства - це історично обумовлені, визнані світовою спільнотою основоположні засади, що знайшли своє відображення у міжнародноправових актах (договорах, статутах, деклараціях тощо), є обов'язковими або рекомендаційними для виконання чи дотримання та запровадження у національну правову систему держав учасниць [10, с. 208].

3 наведеними трактуваннями повною мірою важко погодитися, оскільки, поперше, сьогодні у світі не має жодного міжнародно-правового акта, який був би ратифікований усіма державами. По-друге, вважаємо, що тільки норми-принципи є обов'язковими для виконання, що випливає із закріпленого в ст. 53 Віденській конвенції про право міжнародних договорів терміна «імперативна норма міжнародного права», тобто норма, що приймається і визнається міжнародним співтовариством держав у цілому, а відхилення від ії виконання $\epsilon$ недопустиме, і яка може бути змінена лише наступною нормою загального міжнародного права, що носила 6 такий же характер. Усі інші норми міжнародноправових актів мають лише рекомендаційний характер i, по-перше, спрямовані на оптимізацію та вдосконалення чинного національного законодавства; по-друге, є орієнтиром при формуванні та запровадженні нових положень; по-третє, встановлюють межі втручання у приватне життя, застосування примусу та обмеження прав і свобод людини.

У контексті розгляду процесуального становища потерпілого під час досудового розслідування М. I. Тлепова надала власне бачення щодо поняття міжнародних стандартів захисту прав потерпілого, під якими запропонувала розуміти закріплену в джерелах міжнародного права систему норм і принципів, що на основі загальновизнаних уявлень про права особи встановлює права потерпілого та умови їх обмеження, механізми і гарантії реалізації таких прав, що з урахуванням особливостей порядку правового регулювання мають бути втілені й кон- кретизовані в національних правових системах [11].

М. В. Гузела тлумачить зміст міжнародних стандартів забезпечення прав підозрюваного як закріплення певної мінімальної кількості (об’єму) прав особи, які в разі настання певних умов 6 найбільш незахищеними в процесі здійснення кримінального провадження. При цьому, як зауважує дослідник, такі умови можуть виникнути, здебільшого, в процесі затримання підозрюваного або ж тримання його під вартою. Учений підкреслює, що в багатьох міжнародно-правових актах, які закріплюють права осіб, щодо яких здійснюється кримінальне переслідування, певні їх норми прямо чи опосередковано врегульовують можливість забезпечення прав підозрюваного у вчиненні кримінального правопорушення, а також закріплюють певні гарантії реалізації підозрюваним своїх процесуальних прав [12, с. 189].

Узагальнюючи точки зору щодо визначення поняття «міжнародний стандарт»,О. В. Капліна зазначила, що одні вчені тлумачать його як своєрідний кодекс прав людини в міжнародному праві, інші вважають, що міжнародні стандарти в галузі прав людини - це міжнародно-правові, тобто такі, що випливають з норм міжнародного права, обов'язки держав, треті стверджують, що права людини неможливо імпортувати, оскільки в кожному суспільстві вони мають специфіку, а змісту й духовності вони набувають у державному відокремленому суспільстві. Також дослідниця вказує на існування думки, згідно з якою, незважаючи на встановлення основних прав, свобод і обов'язків громадян найвищими органами державної влади у формі конституційного закону, вони не можуть бути вужчими за змістом від міжнародно-правових стандартів. 3 огляду на різноманіття позицій, учена підтримала думку вчених, згідно 3 якою стосовно кримінального процесу міжнародно-правові стандарти - це норми, які базуються на загальних принципах міжнародного права і регулюють відносини, що складаються у ході їх реалізації у різних сферах кримінального судочинства [13,c. 225]. 


\section{Кримінальне право, кримінальний процес та криміналістика}

Аналізуючи аспекти правозастосування положень нормативних документів, що закріплюють міжнародні правові стандарти прав і свобод людини, К. С. Тищенко зауважив, що поняття міжнародно-правових стандартів у галузі прав людини пов'язане 3 категорією загальновизнаних принципів i норм міжнародного права. Однак у практичному аспекті вказаної категорії спостерігаються певні складності застосування загальновизнаних принципів і норм міжнародного права, тому що вони не закріплені в якомусь єдиному міжнародно-правовому акті [14, с. 330]. Таку думку слід підтримати, оскільки, дійсно, міжнародні правові стандарти захисту прав і свобод людини розпорошені у досить великій кількості документів. I це є цілком виправдана закономірність, адже кожного для в цивілізованій, демократичній, правовій державі відбувається розвиток суспільних відносин, що потребує забезпечення їх захисту.

Як підкреслює С. Є. Щирба, в 1998 році Міжнародною Амністією у Аондоні були розроблені «Десять правозахисних стандартів для правоохоронних органів». Ці правила засновані на стандартах ООН до правоохоронних органів кримінальних процедур та правах людини, суть яких полягає в наступному: 1) кожна людина має право на рівний захист закону, без дискримінації за будь-якими ознаками, особливо від насильства та загроз. Особливу увагу слід приділяти вразливим групам населення - дітям, людям похилого віку, жінкам,біженцям, переселенцям та представникам меншин;2) спрямованість на прояв співчуття та поваги до всіх жертв злочинств, на охорону їх безпеки та приватного життя; 3) незастосування сили, за винятком тих випадків, коли вони суворо необхідні та у мінімально необхідному обсязі; 4) уникнення застосування сили проти незаконних, але мирних зібрань. Розганяючи зібрання із застосуванням насильства, силу слід застосувати у мінімальному обсязі; 5) смертоносну силу слід застосувати лише там, де це абсолютно неминуче, щоб врятувати своє життя або життя інших людей; 6) арешт, який має здійснюватися на достатніх підставах та у відповідності із законними процедурами арешту. Важли- во прослідкувати, щоб усі затримані незабаром після арешту отримали можливість зв'язатися із родичами та юристом, а також отримати необхідну медичну допомогу;7) гуманне поводження з усіма затриманими; 8) недопустимість здійснення позасудових страт чи зникнень; 9) накази щодо здійснення дій, передбачених у 8 пункті, виконанню не підлягають; 10) про всі порушення цих основних стандартів слід повідомляти керівництво та прокуратуру [15, с. 165].

Аналітичний огляд чинних теоретичних поглядів на трактування поняття «міжнародні-правові стандарти захисту прав і свобод людини» дає можливість визначити, що вони розглядаються як багатоаспектне правове явище, а саме як: а) правовий інститут; б) гарантія проти необгрунтованого порушення прав і свобод людини; в) гарантія захисту порушених прав і свобод людини.

Ураховуючи наведені наукові позиції, на нашу думку, під міжнародно-правовими стандартами захисту прав і свобод людини слід розуміти закріплені в загальновизнаних нормативних актах вихідні положення, якими встановлені основі й невід'ємні права і свободи людини, захист яких є обов'язком держави, що ратифікувала відповідний міжнародний договір. Однак вважаємо, що трактування цього поняття здебільшого 6 умовним, оскільки сьогодні у світі прийнято значну кількість міжнародних договорів, які ратифіковані не всіма державами або ж ратифіковані в певній частині чи з певними застереженнями. При цьому вони справляють суттєвий вплив на формування національного законодавства.

Аналіз міжнародних правових актів дозволяє класифікувати міжнародні-правові стандарти у сфері кримінальної юстиції на такі основні категорії: - стандарти здійснення кримінального переслідування відносно особи; - стандарти реалізації права на захист потерпілим як стороною, що зазнала неправомірного порушення прав та свобод, законних інтересів унаслідок вчинення відносно неї злочинів; - стандарти забезпечення прав і свобод особи, щодо якої здійснено кримінальний процесуальний примус (затримання, привід, арешт майна, обшук тощо). 


\section{Висновки}

Вважаємо, що основними напрямами подальших теоретичних досліджень проблем запровадження міжнародно-правових стандартів захисту прав і свобод особи в кримінальному провадженні повинні бути: 1) розроблення відповідної концепції запровадження міжнародно-правових стандартів захисту особи, охорони їі прав, свобод та законних інтересів у кримінальному провадженні; 2) визначення теоретико-правових засад забезпечення прав і свобод особи у кримінальному провадженні через призму міжнародно-правових стандартів; 3) визначення шляхів підвищення ефективності процесуального механізму застосування міжнародно-правових стандартів захисту прав і свобод особи у кримінальному провадженні з обов'язковим урахуванням практики Європейського суду з прав людини.

\section{Аітература}

1. Шаталюк С. Д. Запровадження міжнародних стандартів надання безоплатної правової допомоги в Україні. Наукові прачі Чорноморського державного університету імені Петра Могили. 2012. Вип. 170. С. 92-97.

2. Шейфер С. А. Некоторые вопросы прекращения уголовных дел в стадии дознания и предварительного следствия. Вопросы криминалистики. М., 1961. № 1-2. С. 45-66.

3. Шейфер С. А. Предварительное следствие : общие условия и основные этапы производства. Куйбышев, 1986. 141 с.

4. Орзіх М. Міжнародно-правові стандарти і права людини в Україні. Право України. 1992. № 4. С. 7-9.

5. Тітов С. Б. Система універсальних міжнародних актів по боротьбі з катуваннями та іншими формами негуманного поводження. Форум права. 2014. № 3. С. 383-389.

6. Шепітько I. I. Обвинувальний акт: сутність, зміст та значення для судового розгляду. Право і суспільство. 2017. № 4, ч. 2.C. $216-221$.

7. Шибіко В. П. Проблема забезпечення прав потерпілого за новим КПК України 2012 року. Юридичний часопис начіональної академії внутрішніх справ. 2013. № 1. С. 307313.
8. Юхно О. О. Актуальні проблеми реформування досудового слідства у сучасному стані розвитку і удосконалення кримінального процесуального законодавства України. Вісник Харківсъкого начіонального університету внутрішніх справ. 2012. № 3.C. 156-165.

9. Уваров В. Г. Реалізація рішень Свропейського суду з прав людини та норм міжнародно-правових актів у кримінальному процесі України : автореф. дис. ... д-ра юрид. наук : 12.00.09. Харків, 2014. 40 с.

10. Моторигіна М. Г. Проблеми визначення моменту набуття підозрюваним статусу обвинуваченого. Вісник Харківського начіонального університету імені В. Н. Каразіна. Серія : Право. 2015. № 1151. Вип. 19.C. 208-211.

11. Тлепова М. І. Процесуальне становище потерпілого під час досудового розслідування : дис. ... канд. юрид. наук : 12.00.09. Харків, 2015. 221 с.

12. Гузела М. В. До проблеми прав підозрюваного в кримінальному провадженні: міжнародні стандарти забезпечення. Вісник Аввівського університету. 2016. Вип. 63. С. 187-194.

13. Капліна О. В. Міжнародні-правові стандарти захисту прав потерпілих в кримінальному процесі: інтерпретація і проблеми імплементації в національне законодавство України. Вісник Хмельнииького інституту регіонального управління та права. 2004. № 1-2. C. 223-228.

14. Тищенко К. С. Міжнародні стандарти прав людини: поняття та класифікація. Молодий вчений. 2017. № 12 (52). С. 328-330.

15. Щирба С. С. Вплив міжнародноправових стандартів на діяльність правоохоронних органів України щодо захисту прав людини. Європейські перспективи. 2014. № 7. C. 163-166

\section{Tsyliuryk Inna \\ CURRENT ISSUES OF APPLICATION OF INTERNATIONAL LEGAL STANDARDS DURING THE PRE-TRIAL INVESTIGATION}

The article is devoted to the study of the application of international legal standards during the pre-trial investigation. While writing 


\section{Кримінальне право, кримінальний процес та криміналістика}

the article, the author found that the realities in which Ukraine finds itself in connection with European integration and bringing criminal procedure legislation to the norms and principles of international law, necessitate a rethinking of many provisions of the criminal process. After all, the protection of the rights, freedoms and legitimate interests of the individual, as well as society and the state from criminal offenses in modern conditions can not be ensured without effective compliance with European and international standards of criminal justice, and their implementation in domestic law is especially necessary. Therefore, strengthening procedural guarantees for the realization of rights, freedoms and legitimate interests of a person in criminal proceedings, as well as improving the regulation of criminal proceedings cannot be carried out in isolation from generally accepted international legal standards and practice of the ECtHR as a regulator of legal elements. In the course of the research the author formulated his own conclusions

Today's problems and demands facing Ukraine in connection with the integration process show that the protection of the rights, freedoms and legitimate interests of the individual is becoming increasingly important. Under such conditions, the development and practical implementation of effective legal mechanisms to protect the rights, freedoms and legitimate interests of the individual is impossible without taking into account generally accepted international legal standards and principles in this area. That is why, in our opinion, further improvement of the criminal procedural legislation of Ukraine, the introduction of new institutions should take place only in accordance with generally accepted European standards and principles of criminal justice. So, of course, at this historical stage of development of our state, the issue raised requires understanding the nature and legal nature of international legal standards for the protection of the individual in criminal proceedings.

Given the priority of this area, Ukraine is currently actively supporting international cooperation with members of the European community in various fields, which requires permanent accession to existing multilateral international agreements. On this basis, the national legislation is brought into line with generally accepted norms and standards. In particular, this applies to the criminal process in Ukraine, which is a specific type of activity of authorized officials who, within the limits and in the manner prescribed by law, may apply restrictive measures (detention, pretext, seizure, seizure of property, election of precautionary measures, etc.).

It is concluded that the main directions of further theoretical research on the implementation of international legal standards for the protection of human rights and freedoms in criminal proceedings should be: 1) development of an appropriate concept for the implementation of international legal standards for protection criminal proceedings; 2) determination of theoretical and legal bases of ensuring the rights and freedoms of a person in criminal proceedings through the prism of international legal standards; 3 ) identification of ways to increase the effectiveness of the procedural mechanism for the application of international legal standards for the protection of individual rights and freedoms in criminal proceedings, with due regard for the case law of the European Court of Human Rights. 